TEKNIK, 41 (1), 2020, 9-13

\title{
Study of the Effect of Bulb Ratio and Blade Angle on Propeller Turbine Performance in Horizontal Flow using Numerical Simulation
}

\author{
Akhmad Nurdin, Dwi Aries Himawanto*, Syamsul Hadi \\ Departement of Mechanical Engineering, Faculty of Engineering, Sebelas Maret University, \\ Jl. Ir Sutami NO.36 A, Surakarta, Indonesia 57126
}

\begin{abstract}
This paper discusses numerical simulations of horizontal flow propeller turbines. Static bulbs located before the turbine can be used to increase water velocity and potentially increase the turbine's performance. The blade angle affects the gap between the blades, and this will also affect the performance of the turbine. Numerical simulations were conducted by using software Solid Works Flow Simulation 2016 and by using five blades in a static state. This study aimed to determine the effect of the bulb ratio and blade angle on the propeller turbine characteristics on horizontal flow. Bulb Ratio variations used in this study were 0, 0.4, 0.6, and 0.8, while the angle variations used were 20, 25, and 30 degrees. Each variation was tested at $0.02 \mathrm{m3} / \mathrm{second}$. The results of this study indicated that the bulb ratio 0.6 with the 25-degree blade angle produces the highest torque.
\end{abstract}

Keywords: bulb ratio; blade angle; propeller; turbine; static bulb; solidworks

\section{Introduction}

There is a worldwide development on smallscale hydroelectric power plants (or hydropower) because it is clean, sustainable, and emission-free. Small hydropower is classified based on the power produced, which is mini (less than $100 \mathrm{~kW}$ ), micro or pico (less than $5 \mathrm{~kW}$ ) (Samora et al. 2016). Micro or pico scale (less than $5 \mathrm{~kW}$ ) manufacturing processes are generally relatively cheap. They can be applied to small streams or water supply systems, so suitable for remote areas. The manufacturer required micro/pico hydro costs per unit of energy are lower than using solar panels, wind energy, or fossil fuel generator (Ramos, Borga, and Simão 2009).

Many types of water turbine systems are used to produce electrical energy. Water turbines function to convert water energy into mechanical energy. Among the widely used turbine forms, the reaction turbine works by converting water pressure to kinetic energy, then pounding the rotor to turn the turbine shaft (Dariusz, Tomasz \& Damian 2015). At low heads with high discharge, the reaction turbine's performance is better than that of the implant turbine. Meanwhile, to the low-speed operation, the efficiency of the reaction turbine is generally higher than that of the implant turbine. Several types of

\footnotetext{
${ }^{*}$ Corresponding author

E-mail: dwiarieshimawanto@gmail.com
}

reaction turbines, axial turbines are widely used. Not only practical, but propeller turbines are also efficient, simple and cost-effective. Based on its shape, there are four types of propellers, namely tube turbine, starflo, kaplan, and turbine bulb (Elbatran et al. 2015). In horizontal flow and significant flow rate in pipe flow, the type of bulb turbine shows higher performance, so it is used more than others (Zhu et al. 2012). The geometry of a propeller turbine affects the turbine's performance, one of which is the blade angle, which affects the gap between the blades (Farhan, 2016).

Numerical method analysis shows the phenomenon in detail and accurately (Nurdin \& Himawanto 2019). Therefore, it can be used as support in experimental method analysis. Using numerical analysis with simulations, the flow phenomena that occur in turbines can be clearly described. By reducing research cost and time, the numerical method is more effective than the experimental method (Shukla \& Parashar 2017).

This study's main objective is to analyze the effect of bulb ratio and blade angle on propeller turbine performance on horizontal flow using the SolidWorks 2016 Flow Simulation software. This paper shows the torque value of the turbine under static conditions, while also showing the flow pressure contour before the turbine and pressure contours on the turbine surface. 


\section{TEKNIK, 41 (1), 2020, 10}

\section{Researh Method}

Turbine design refers to previous studies, the and outlet hubs an angle of 41 and 17 degrees, as well as inlet and outlet tip angles of 26 and 17 degrees. The hub diameter is $42.25 \mathrm{~mm}$ (Ramos, Simão, and Borga 2013), and the tip diameter is $84.8 \mathrm{~mm}$ (Samora et al. 2016). The design of the static bulb and turbine house used in reference (Zhu et al. 2012). The variables of this study are the ratio of the bulb to the input pipe and blade angle. Bulb ratio variations are $0,0.4,0.6$, and 0.8 shown in Fig. 1, while angle variations in blade design are 20, 25, and 30 degrees shown in Fig.2.

For accurate simulation results, meshing validation is performed. The first step is the validation of the meshing level. The optimal level shows changes in the result that are slightly different from the results before and after (Sakti et al. 2019). Variables with a bulb ratio of 0.6 with the 20 degrees' blade angle are used for meshing validation. They are shown in Fig. 3. Based on the results of the first validation shown in Fig 3, level 5 meshing shows stable results compared to the others. In the next step, the results of the meshing validation were carried out on previous reference studies. In this step, validation was done in reference to research (Farhan, 2016) using level meshing 5. The results of this validation are shown in Fig. 4 with the results slightly differently. Based on the validation results, meshing at level 5 is suitable for use in this study. The boundary conditions were shown in Fig 5. The simulation inlet uses a parameter flow inlet volume of $0.013 \mathrm{~m} 3$ / s, while the outlet is using environmental pressure or $101325 \mathrm{~Pa}$. This simulation object is the static torque of the turbine in the flow direction (x), with the parameters used by SG Torque (X) in the turbine.

\section{Result and Discussion}

Numerical method simulation results in the form of static torque values are shown in Fig 6. Optimum torque values in this study occur at the 0.6 bulb ratio; from the 0 bulb ratio, the torque value will rise until the 0.6 bulb ratio. Then, the torque decreases suddenly at the 0.8 bulb ratio. At the same time, the 25-degree blade angle shows the most optimal value compared to another angle. In general, Fig 6 shows the ratio of the bulb with the 25 -degree blade angle producing the most considerable torque value in this study. An increase in torque value in the bulb ratio of 0 to 0.6 is due to the narrowing of the area to increase the velocity of the water, as shown in Fig 7, the different velocity contours in the bulb ratio 0 and 0.6 (at the 25 -degree blade angle). At the 0.6 bulb ratio, there are several increased velocity before the turbine pounding, thus increasing the torque value compared to the bulb ratio 0 . At the static bulb, the water's velocity begins to rise after passing through the bulb body. Then the increase in velocity occurs again before and after entering the turbine housing. The velocity drops suddenly after the water hits the blades (Chen et al. 2014).
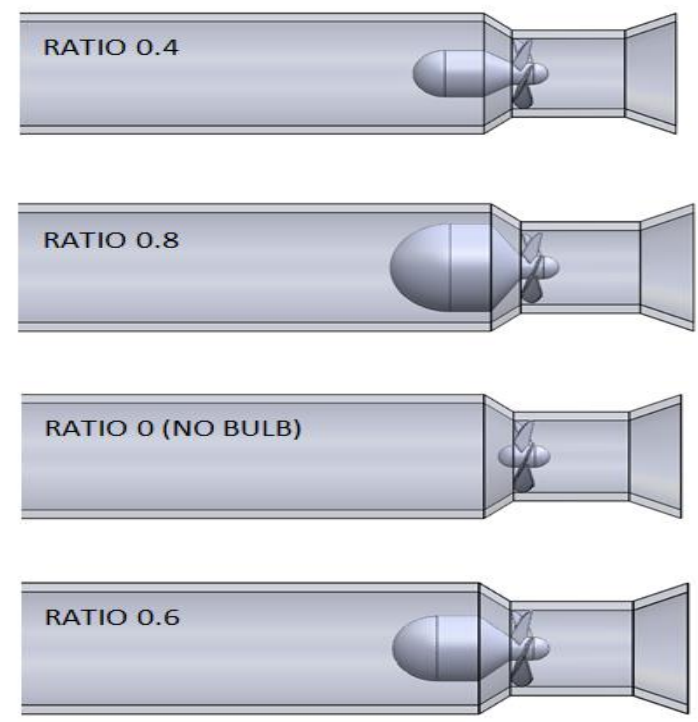

Figure 1. Bulb Ratio Variation
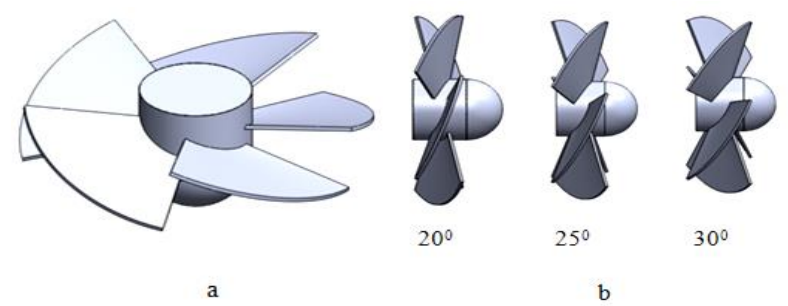

Figure 2. (a) Propeller turbine design (b) Blade angle variations

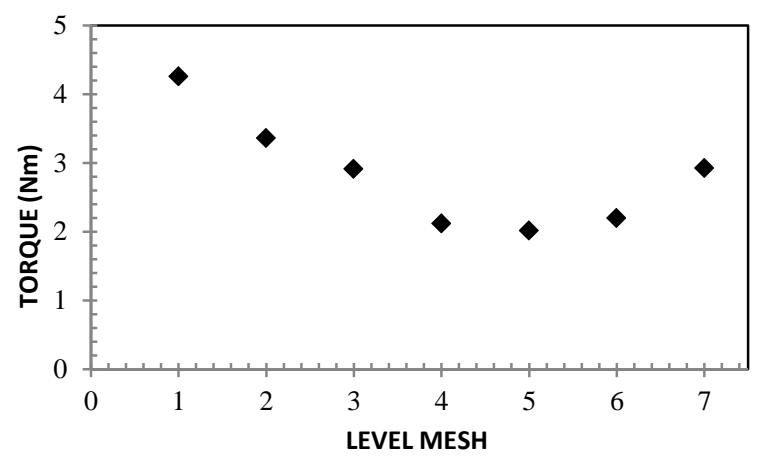

Figure 3. Meshing validation result 


\section{TEKNIK, 41 (1), 2020, 11}
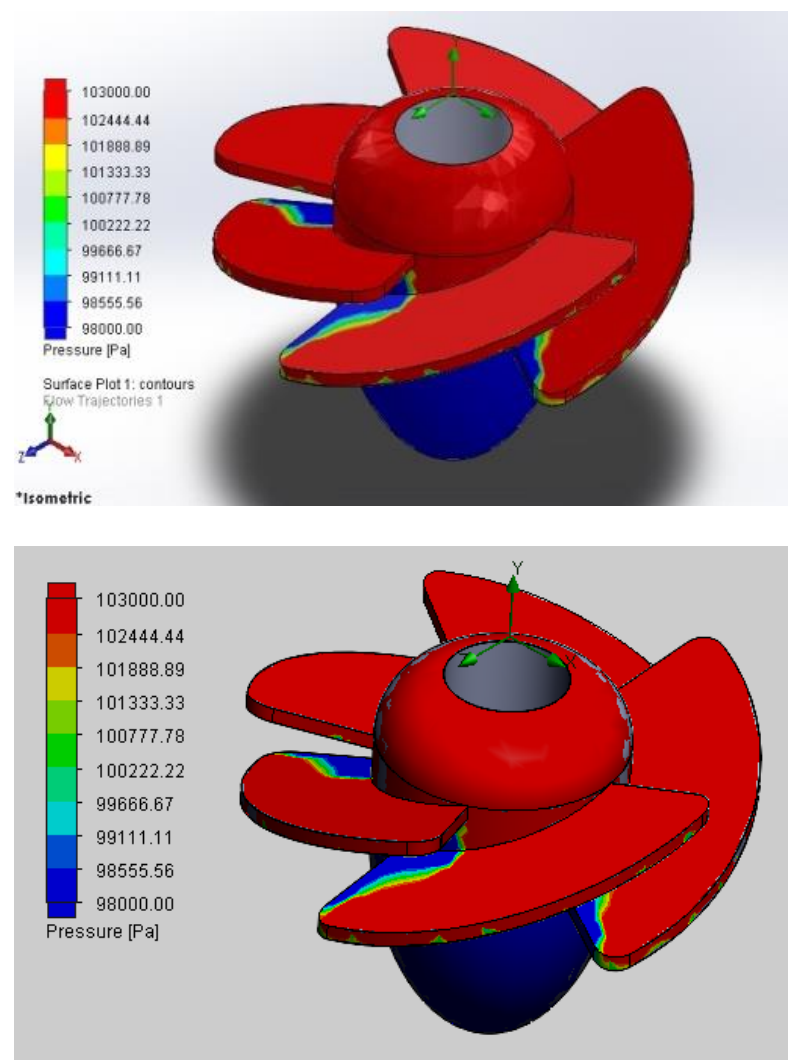

Figure 4. (a) Reference validation (Farhan 2016) (b) Simulation result

While the decrease in torque value occurs at the 0.8 bulb ratio, this decrease is due to obstruction of flow when the water passes through the bulb body before pounding the blade. As shown in Fig 8, the contour pressure illustrates the flow blocked at the bulb ratio 0.8 was higher than the contour pressure at bulb 0.6 (at the 25-degree blade angle). Thus the pressure of water flow when pounding a turbine is reduced compared to the 0.6 bulb ratio. This is shown in Fig 9 pressure contours that occur on the blade ( 25 degrees) surface at the bulb ratio 0.8 lower than the bulb ratio 0.6

Figure 6 shows the 25-degree blade angle at each bulb ratio producing the highest torque value compared to the 20-degree blade angle. In contrast, the lowest torque value occurs at the 30-degree blade angle. Fig 10 shows the pressure contour on the turbine surface (bulb ratio 0.6). At the 20-degree blade angle, the pressure contour is higher than at 25-degree, this is due to at the blade angle 20degree, the gap between the blades is too narrow, so water flow is blocked. The contour pressure at the 30-degree blade angle was lower than at 25-degree; this is due to the axial force of the water, which does not entirely hit the blade. The blade does not properly convert the flow of water (Shalih, 2018).

The variable of the blade angle on the propeller turbine will change the blades' gap so that the water flow will also be affected. As shown in Fig 11 at the 20-degree blade angle, the highest pressure contour occurs compared to others, is due to the water flow being blocked when passing through the turbine. While on at the 30-degree blade angle, the lowest pressure contour occurs compared to others, because the water flow is not blocked when passing through the turbine.

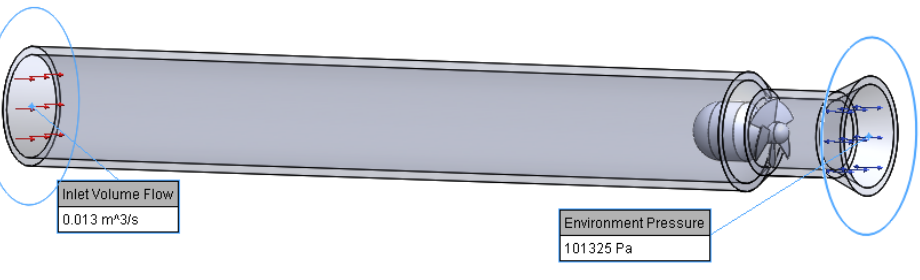

Figure 5. Boundary condition

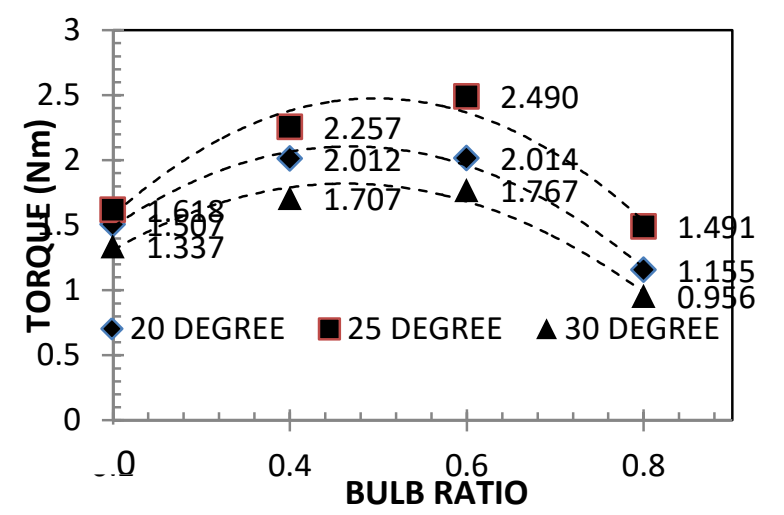

Figure 6. Realitionship between bulb ratio and blade angle vs torque

\section{Conclusion}

In general, this study shows the effect of bulb ratio and blade angle on horizontal flow propeller turbine characteristics using numerical simulations. Based on the results of simulations carried out, the higher the value of the bulb ratio until 0.6 increases the torque value of the propeller turbine, then down to the ratio of 0.8 . Meanwhile, at the 25-degree blade angle shows the highest torque value compared to others. Finally, in this study, the design of propeller turbines with a 0.6 bulb ratio with the 25-degree blade angle has the most optimal torque value compared to others applied at horizontal flow. 


\section{TEKNIK, 41 (1), 2020, 12}

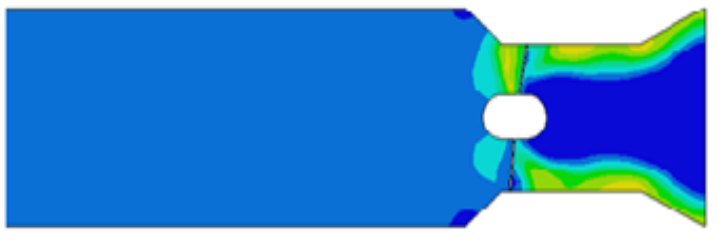

(a)

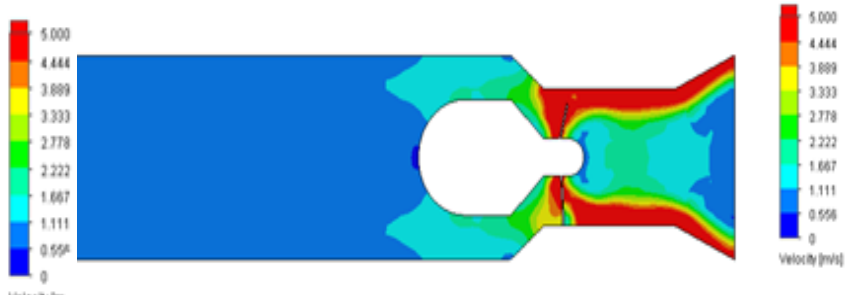

(b)

Figure 7. Water flow velocity contours at the 25-degree blade angle, bulb ratio 0 (a) and bulb ratio 0.6 (b)

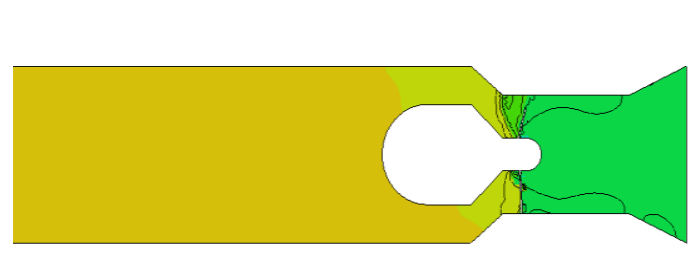

(a)

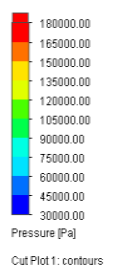

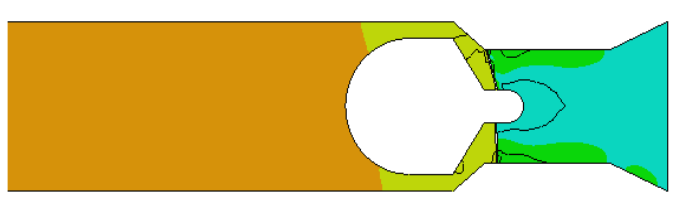

(b)

Figure 8. Water flow pressure contours at the 25-degree blade angle, bulb ratio 0.6 (a) and bulb ratio 0.8 (b)

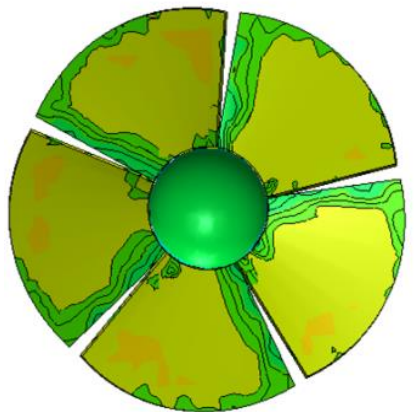

(a)
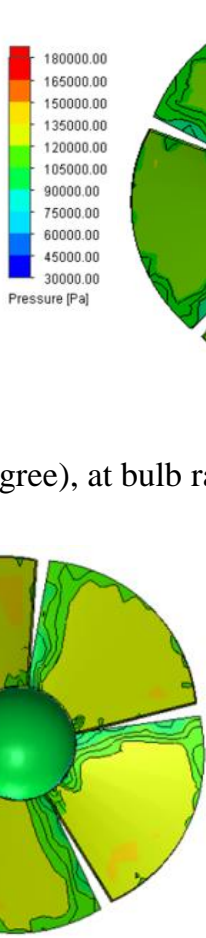

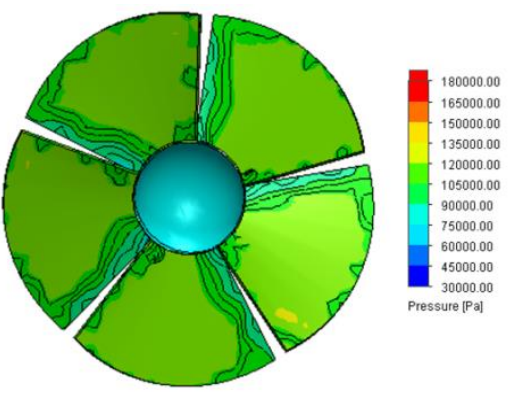

(b)

Figure 9. Pressure contours at surface blade (25-degree), at bulb ratio 0.6 (a) and bulb ratio 0.8 (b)

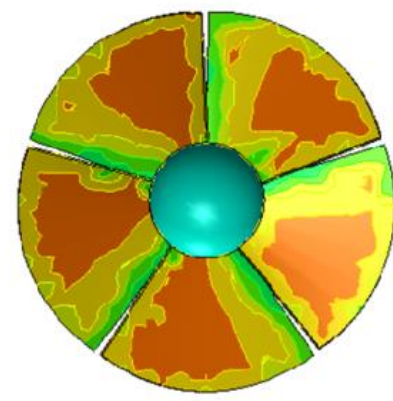

(a)

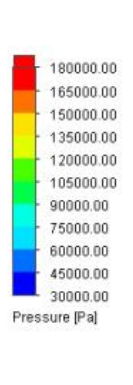

(b)

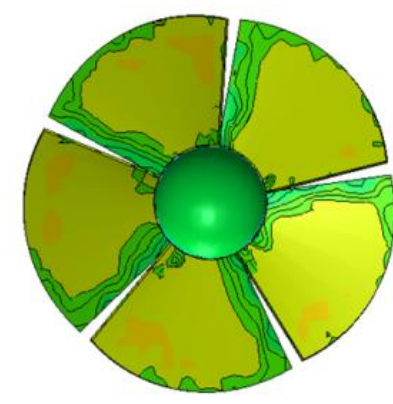

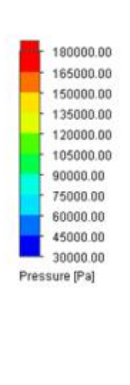

Figure 10. Pressure contours at surface blade at bulb ratio 0.6

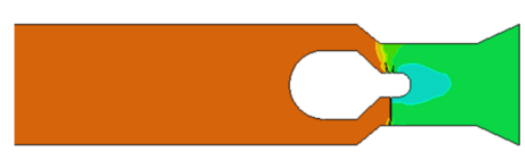

(a)

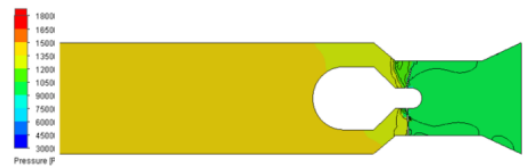

(b)

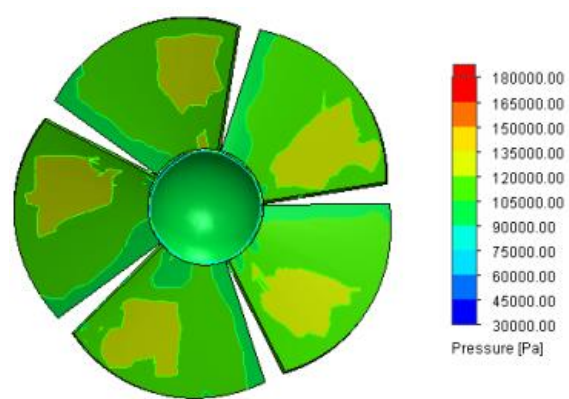

(c)

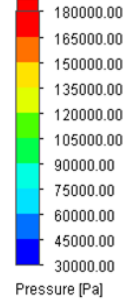

Pressure [Pa] ) 


\section{TEKNIK, 41 (1), 2020, 13}

\section{References}

Chen, Z., Joo-cheong, K., Myeong-hwan, I.\& Youngdo, C.(2014). Analysis on the Performance and Internal Flow of a Tubular Type Hydro Turbine for Vessel Cooling System 2. Turbine Model and Numerical Methods, 38(10),1244-50.

Dariusz, B., Tomasz , W., \& Damian, L. (2015). Electrical Energy Recovery From Network Water Pressure. Selected Problems of Electrical Engineering and Electronics (WZEE), Kielce, 1-6"

Elbatran, A. H., Yaakob, O. B., Ahmed, Y. M. \& Shabara, H. M. (2015). Operation, Performance and Economic Analysis of Low Head Micro-Hydropower Turbines for Rural and Remote Areas: A Review. Renewable and Sustainable Energy Reviews (43), 40-50.

Farhan, A. P. (2016). Optimalisasi Desain Turbin PLTA Pico- Hydro Untuk Meningkatkan Efisiensi Daya Dengan Bantuan Software CFD Dan Konsep Reverse Engineering. Skripsi Fakultas Teknik Jurusan Teknik Mesin Universitas Sebelas Maret.

Nurdin, A. \& Himawanto, D.A.( 2019). Studi Numerik Kekuatan Material Transmisi Roda Gigi Pico Hydro. Jurnal Teknik Mesin Indonesia, 14(1), 2429.

Ramos, H. M., Simão, M. \& Borga, A. (2013). Experiments and CFD Analyses for a New Reaction Microhydro Propeller with Five Blades. Journal of Energy Engineering ,139 (2), 109-17.

Ramos, H.M, Borga, A. \& Simão, M. (2009). New Design Solutions for Low-Power Energy Production in Water Pipe Systems. Water Science and Engineering, 2(4), 69-84.
Sakti, A., Prasetyo, A., Tjahjana D. P. \& Hadi, S. ( 2019). The Horizontal Axis Type of Savonius Water Turbine in Pipe Using Solidwork Simulation The Horizontal Axis Type of Savonius Water Turbine in Pipe Using SolidWork Simulation" $030042 \quad$ (April): 1-6. https://doi.org/10.1063/1.5098217.

Samora, I., Hasmatuchi, V., Münch-Alligné, C., Franca, M., J., Schleiss, A. J., \& Ramos, H. M. (2016). Experimental Characterization of a Five Blade Tubular Propeller Turbine for Pipe Inline Installation. Renewable Energy, 95, 356-66. https://doi.org/10.1016/j.renene.2016.04.023.

Shalih, A. (2018). Studi Eksperimental Pengaruh Sudut Kemiringan Sudu Terhadap Unjuk Kerja Turbin Propeler Pikohidro. Skripsi Fakultas Teknik Jurusan Teknik Mesin. Universitas Sebelas Maret.

Shukla, R. S., \& Parashar, C.(2017). Design of Propeller Turbine for Micro Hydro Power Station Using CFD. International Journal of Scientific Engineering and Science, 1(7), 37-41.

Zhu, L., H. P. Zhang, J. G., Meng , X. C. \& Lu, L.(2012). Performance of a Bulb Turbine Suitable for Low Prototype Head: Model Test and Transient Numerical Simulation Performance of a Bulb Turbine Suitable for Low Prototype Head : Model Test and Transient Numerical Simulation." IOP Conference Series: Earth and Environmental Science 5 (part 4). https://doi.org/10.1088/1755$1315 / 15 / 4 / 042032$ 